\title{
The Epidemiology of COVID-19 Novel Corona Virus in Incidence and the Distribution of the Disease across the World
}

\author{
Ahsan Ali Siddiqui* \\ Quality Management and Patient Safety Department, Ministry of Health, Saudi Arabia
}

*Corresponding author: Ahsan Ali Siddiqui, Consultant Preventive Medicine and Epidemiologist, Quality Management and Patient Safety Department, Ministry of Health, Riyadh, Saudi Arabia

To Cite This Article: Ahsan Ali Siddiqui. The Epidemiology of COVID-19 Novel Corona Virus in Incidence and the Distribution of the Disease across the World. 2020 - 9(4). AJBSR.MS.ID.001407. DOI: 10.34297/AJBSR.2020.09.001407.

Received: May 24, 2020; Published: 眥 July 09, 2020

\begin{abstract}
Background and Objective: This Article focuses on providing details about the origin of the COVID-19 and the distribution among the community. Which part of community in Age, Gender, race and with chronic illness are more vulnerable to get COVID-19. COVID-19 Corona virus attacks on Lungs, Heart and other viscera of the body till a person died. The study focuses on two things which Articles are in favor of immediate Governmental actions against the Pandemic COVID-19, Which Articles discusses the Preventive measures about the COVID-19?

Methods: The Author of this Article has selected various Randomly selected Publications to study the Epidemiology of COVID-19 its Incidence Distribution and Control measures. The Author has focused on Literature Review of the Articles suggesting the Important role of Governments and their Health Agencies to fight against COVID-19 Pandemic. The Preventive methods on Educating local population and providing Personal Protective Equipment's for Health care workers and Front-line staff, Security staff and other organizations.

Results: The Author of this Article has represented the Review of 20 Different Articles about two things. Firstly, after data collection of 12 Randomly selected Articles that 9 Articles fully support of immediate Governmental actions against the Pandemic COVID-19. Second, all 10 randomly selected Articles discusses the Preventive measures about the COVID-19. The Author has used SPSS 19 software for Diagrammatic presentation of the data and for results.

Conclusion: Current Pandemic of COVID-19 novel corona virus has taught us a lesson that Global Health Agencies and Governments of the countries are not prepare for such Pandemic. The Governments has acted slowly or irresponsibly for the fight against COVID-19 Pandemic. Due to slow action to implement Preventive actions against COVID-19 approximately 300,000 people have lost their lives and more than four million people are Infected across the world. Better preparations are needed in the future to fight against such a cruel Pandemic disease.
\end{abstract}

Keywords: Severe acute respiratory syndrome coronavirus-2, Epidemiology, Clinical, Pathology, Treatment, COVID-19, MERS-CoV, SARS-CoV-2, Saudi Arabia, Pandemic, Racial and ethnic disparities, Basic reproduction number, Incubation period, Serial interval, diabetes mellitus, hypertension.

\section{Introduction}

The outbreak of emerging severe acute respiratory syndrome coronavirus 2 (SARS-CoV-2) disease (COVID-19) in China has been brought to global attention and declared a pandemic by the World Health Organization (WHO) on March 11, 2020. Scientific advancements since the pandemic of severe acute respiratory syndrome (SARS) in 2002-2003 and Middle East respiratory syndrome (MERS) in 2012 have accelerated our understanding of the epidemiology and pathogenesis of SARS-CoV-2 and the development of therapeutics to treat viral infection. As no specific therapeutics and vaccines are available for disease control, the epidemic of COVID-19 is posing a great threat for global public health [1].

A pandemic of 2019 novel coronavirus [2] (COVID-19) is an international problem and factors associated with increased risk of mortality have been reported. However there exists limited statistical method to estimate a comprehensive risk for a case in which a patient has several characteristics and symptoms concurrently. We applied Boolean Monte Carlo method (BMCM) to the Novel Corona Virus 2019 Dataset to determine interrelation of patient's char- 
acteristics and symptoms. In the analyses, age, fever as an onset symptom, and sex were used as explanatory variables, and death as the objective variable. Among 265 patients included in the analysis the interrelations for estimating death were determined as age and fever and sex ( $p<0.0001$ for both operators) [2].

The bats [3] are the most probable original reservoir based on the current evidence. However, it is notable that Wuhan Huanan seafood market may not be the only source of SARS-CoV-2 spreading globally. Cohen pointed out Wuhan Huanan seafood market was not the only origin of SARS-CoV-2 by analyzing the epidemiology of 41 cases in the earliest study. Pangolins may act as one of intermediate hosts. More work is needed to provide more precise information about original reservoir and intermediate hosts of SARSCoV-2. Table 1 lists some information of studies about the genome sequence identity with SARS-CoV-2. Figure1 shows the genome structure of SARS-CoV-2 in different studies. In the genome of coronaviruses, the gene of ORF1a and ORF1b occupies about two thirds of the overall genome [3] encoding 16 non-structural proteins (nsps) while the remaining one-third encodes accessory proteins and structural proteins (Figure $1 \& 2$ ).

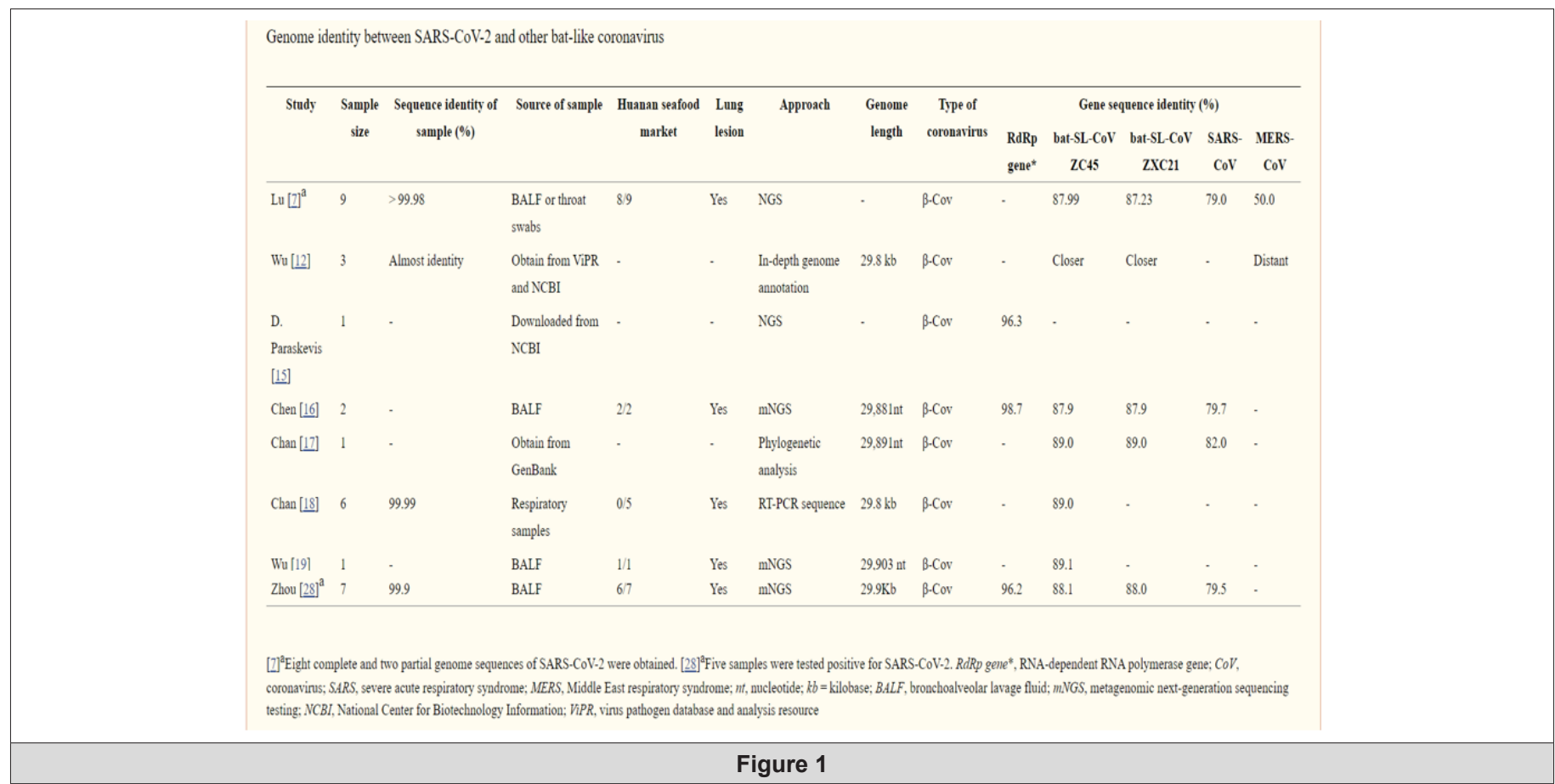

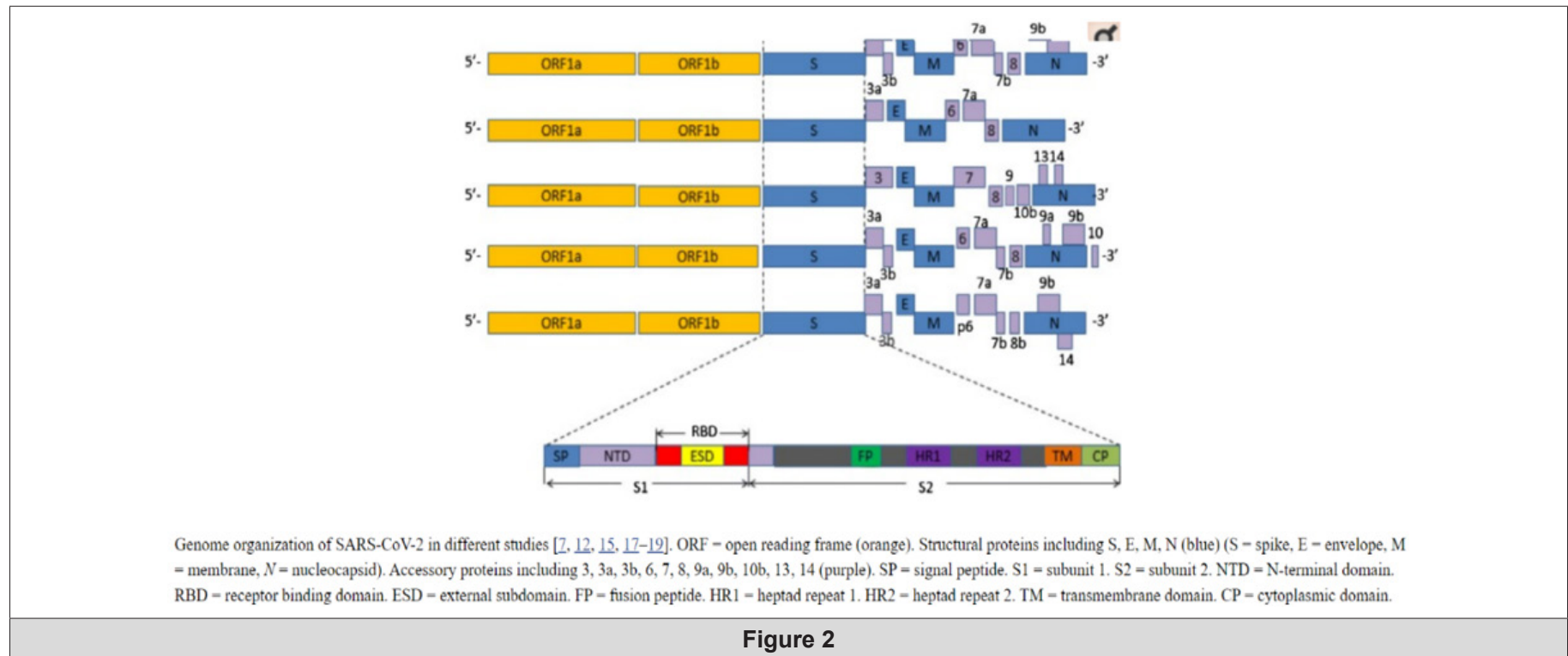

Five of seven human coronavirus [4] was isolated in this century. Unfortunately, last three of them entered our life with a fear of outbreak, pandemic or death. Initial reports showed that, its origin was bats. It transmitted human to human by droplet and contact routes, but some doubt about airborne, fecal or intrauterine transmission also should be removed. Its R0 value is 2.3 but it could be 
as high as 5.7. Its case fatality rate was 6.3 , but it was different in different ages and counties, and it could be over $15 \%$. According to early models total 10-12 weeks is required to control an outbreak in the community. While different countries show different daily case numbers, total number of cases, case mortality rates or R0 [4] it seems they show a similar epidemic curve.

Coronaviruses are [5] enveloped positive single-stranded large RNA viruses that infect humans but also a wide range of animals.
Coronaviruses were first described in 1966 by Tyrell and Bynoe who cultivated the viruses from patients with common colds. Based on their morphology as spherical virions with a core shell and surface projections resembling a solar corona, they were termed coronaviruses (Latin: corona $=$ crown). Four subfamilies namely alpha, beta, gamma and delta coronaviruses exist. While alpha and beta coronaviruses apparently originate from mammals in particular from bats gamma and delta viruses originate from pigs and birds [5] (Figure 3).

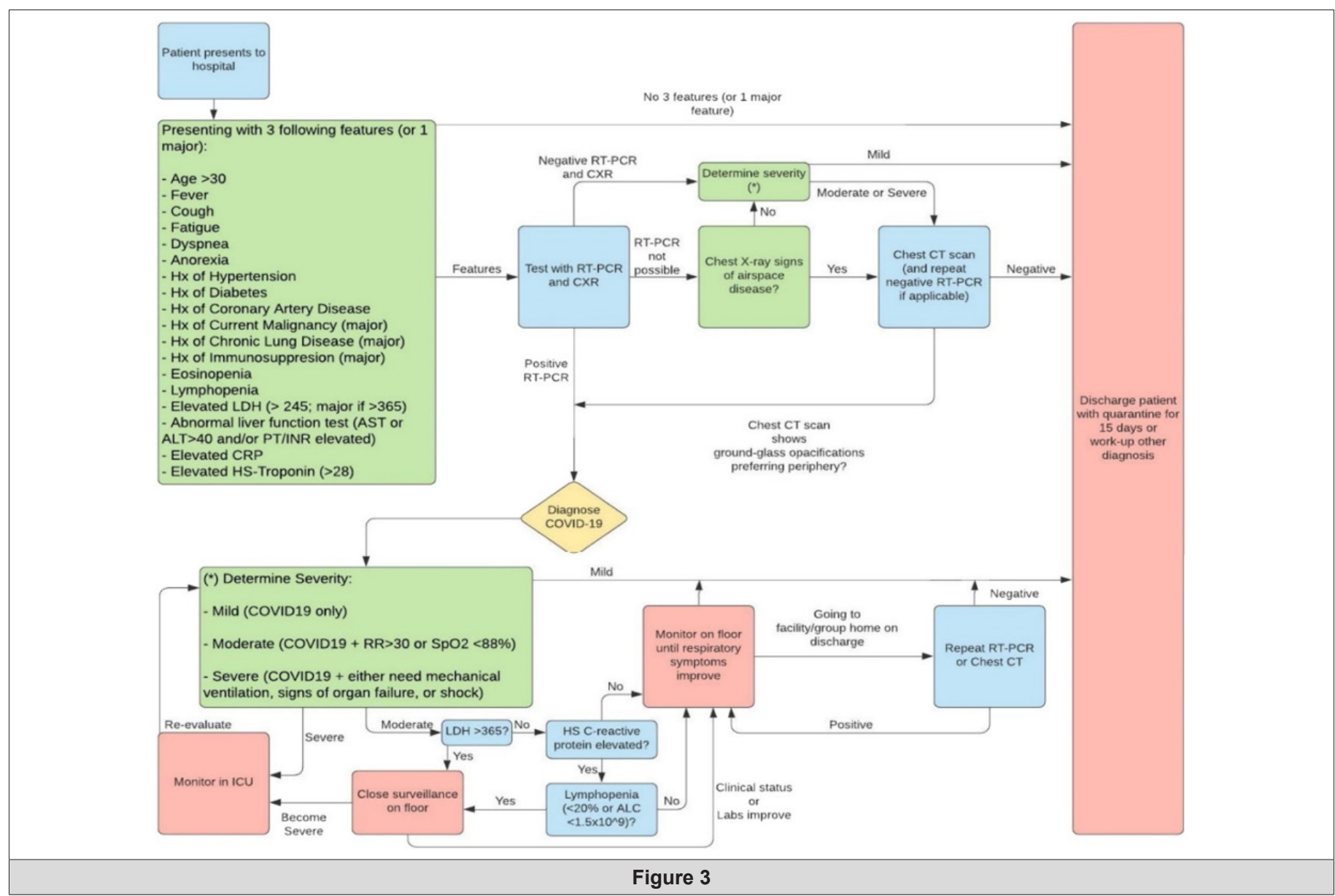

An epidemic of extreme respiratory [6] deterrence pneumonia and shortness of breath the SARS-CoV-2 viral infection began in Wuhan, Hubei Province China. Most COVID-19 patients were diagnosed with pneumonia and many were treated using Chinese medicines and other secondary therapies. As of April 22, 2020, the total figure of infected patients has crossed 2.6 million people worldwide with over 180,000 deaths and 700,000 patients that have recovered. Preliminary reports suggest that certain drugs such as chloroquine and antiviral nucleotide analogues such as remdesivir, which inhibit viral replication can target the new coronavirus although their usefulness in the clinic is still under debate [6].

\section{Methods}

The Author of this Article has selected various Randomly selected Publications to study the Epidemiology of COVID-19 its Incidence Distribution and Control measures. The Author has focused on Literature Review of the Articles suggesting the Important role of Governments and their Health Agencies to Fight against COVID-19 Pandemic. The Preventive methods on Educating local population and providing Personal Protective Equipment's for Health care workers and Front-line staff, Security staff and other organizations (Figure 4) (Table 1,1a,2,2a).

\section{Results}

The Author of this Article has represented the Review of 20 Different Articles about two things. Firstly, after data collection of 12 Randomly selected Articles that 9 Articles fully support of immediate Governmental actions against the Pandemic COVID-19. Second, all 10 randomly selected Articles discusses the Preventive measures about the COVID-19. The Author has used SPSS 19 software for Diagrammatic presentation of the data and for results [7-9]. 
(A)

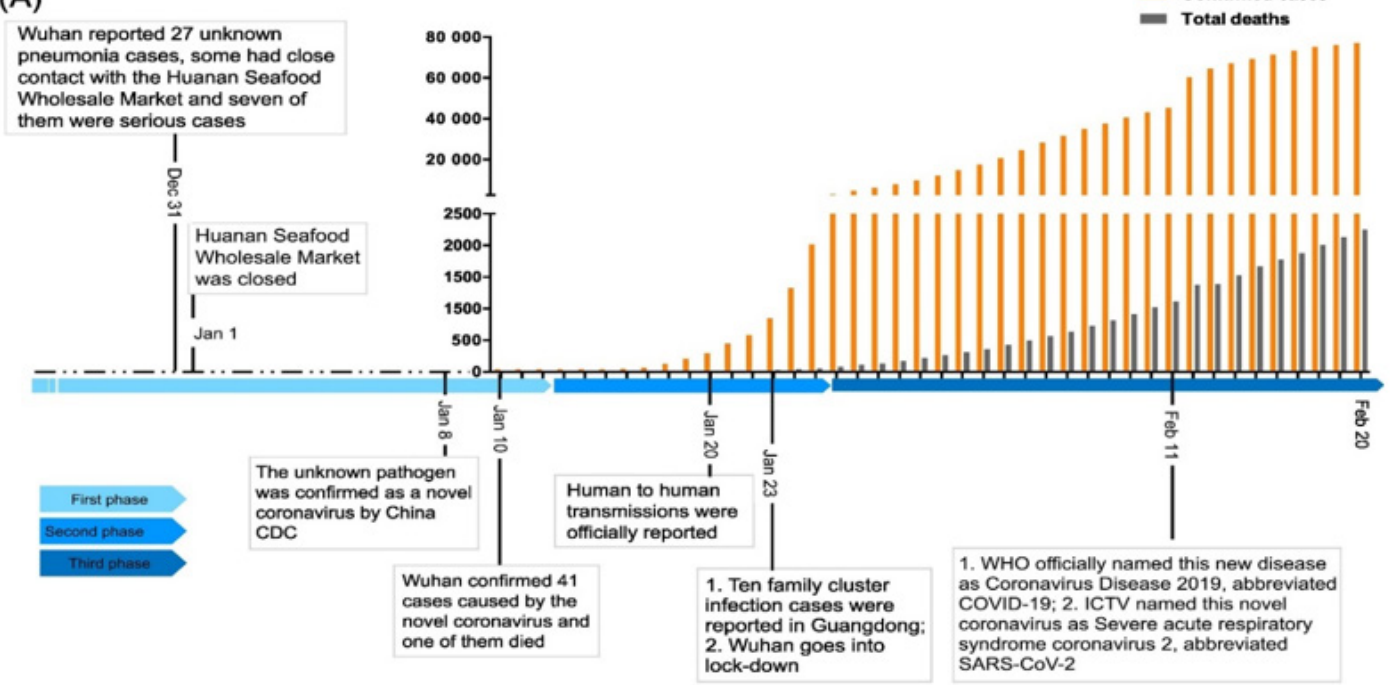

(B)

(C)
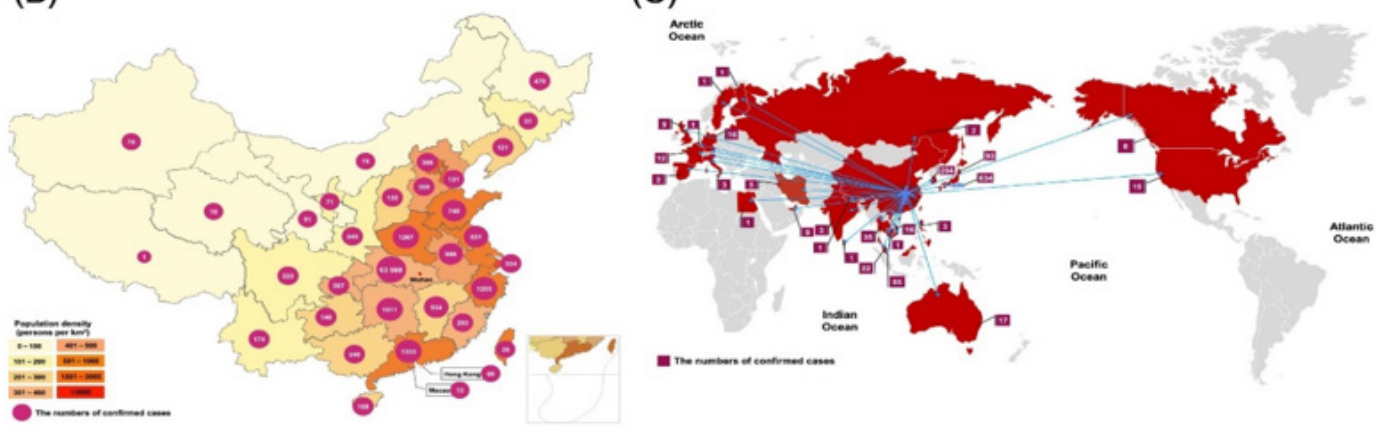

Figure 4

Table 1: 12 Randomly selected Articles that explain the Government role in control of Pandemic of COVID-19 Novel corona virus.

\begin{tabular}{|c|c|c|c|c|}
\hline S.NO & $\begin{array}{l}\text { Complete Reference of the Articles selected for } \\
\text { study }\end{array}$ & $\begin{array}{l}\text { Study favors Government } \\
\text { role in control of Pan- } \\
\text { demic of COVID-19 Novel } \\
\text { corona virus: }\end{array}$ & $\begin{array}{l}\text { Study against } \\
\text { Government role in } \\
\text { control of Pandemic } \\
\text { of COVID-19 Novel }\end{array}$ & $\begin{array}{c}\text { Percentage of Study } \\
\text { favors Government role } \\
\text { in control of Pandemic of } \\
\text { COVID-19 Novel }\end{array}$ \\
\hline 1 & $\begin{array}{c}\text { Xiaodong Zhang (2020) Epidemiology of Covid-19. The } \\
\text { New England Journal of Medicine. 382:1869-1870. DOI: } \\
10.1056 / \text { NEJMc2005157 }\end{array}$ & YES & ------ & $100 \%$ \\
\hline 2 & $\begin{array}{l}\text { Huipeng Ge, Xiufen Wang, Xiangning Yuan, Gong Xiao } \\
\text { et al (2020) The epidemiology and clinical information } \\
\text { about COVID-19. European Journal of Clinical Micro- } \\
\text { biology \& Infectious Diseases. 2020 Apr 14: 1-9. doi: } \\
\text { 10.1007/s10096-020-03874-z. }\end{array}$ & YES & ------. & $100 \%$ \\
\hline 3 & $\begin{array}{l}\text { Barry M, Al Amri M, Memish ZA (2020) COVID-19 in the } \\
\text { Shadows of MERS-CoV in the Kingdom of Saudi Arabia. } \\
\text { Journal of Epidemiology and Global Health. } 10 \text { (1): 1-3. } \\
\text { doi: } 10.2991 / \text { jegh.k.200218.003. }\end{array}$ & YES & ------. & $100 \%$ \\
\hline 4 & $\begin{array}{l}\text { Yuanyuan Dong, Xi Mo, Yabin Hu, Xin Qi et al, (2020) } \\
\text { Epidemiology of COVID-19 Among Children in China. } \\
\text { Pediatrics Official Journal of the American Academy } \\
\text { of Pediatrics. } 145 \text { (5): e20200702; DOI: https://doi. } \\
\text { org/10.1542/peds.2020-0702. }\end{array}$ & Partially & ------ & $50 \%$ \\
\hline 5 & $\begin{array}{l}\text { Qifang Bi, Yongsheng Wu, Shujiang Mei et al (2020) } \\
\text { Epidemiology and transmission of COVID-19 in } 391 \\
\text { cases and } 1286 \text { of their close contacts in Shenzhen, Chi- } \\
\text { na: a retrospective cohort study. The Lancet Infectious } \\
\text { Diseases. April 27, 2020 DOI:https:// doi.org/10.1016/ } \\
\text { S1473-3099(20)30287-5. }\end{array}$ & YES & ------ & $100 \%$ \\
\hline
\end{tabular}




\begin{tabular}{|c|c|c|c|c|}
\hline 6 & $\begin{array}{l}\text { Jiumeng Sun, Wan-Ting He, Lifang Wang et al, (2020) } \\
\text { COVID-19: Epidemiology, Evolution, and Cross-Disci- } \\
\text { plinary Perspectives. Trends in Molecular Medicine, Cell } \\
\text { Press Reviews. } 26 \text { (5): 483-495. }\end{array}$ & Partially & ------ & $50 \%$ \\
\hline 7 & $\begin{array}{l}\text { Ornelas-Aguirre JM (2020) The new coronavirus that } \\
\text { came from the East: analysis of the initial epidemic in } \\
\text { Mexico. Gaceta Medica de Mexico. } 2020 \text { May 14;156 (4). }\end{array}$ & YES & ------- & $100 \%$ \\
\hline 8 & $\begin{array}{c}\text { Komenda M, Bulhart V, Karolyi M, Jarkovský J et al } \\
\text { (2020) Complex Reporting of Coronavirus Disease } \\
\text { (COVID-19) Epidemic in the Czech Republic: Use of } \\
\text { Interactive Web-Based Application in Practice. Journal } \\
\text { of Medical Internet Research. } 2020 \text { May 14. doi: } \\
\text { 10.2196/19367. }\end{array}$ & YES & ------ & $100 \%$ \\
\hline 9 & $\begin{array}{l}\text { Henning-Smith C, Tuttle M, Kozhimannil KB (2020) } \\
\text { Unequal Distribution of COVID-19 Risk among Rural } \\
\text { Residents by Race and Ethnicity. The Journal of Rural } \\
\text { Health. } 2020 \text { May } 12 . \text { doi: } 10.1111 / \text { jrh.12463. }\end{array}$ & YES & ------ & $100 \%$ \\
\hline 10 & $\begin{array}{c}\text { Fan J, Liu X, Shao G et al (2020) The epidemiology } \\
\text { of reverse transmission of COVID-19 in Gansu Prov- } \\
\text { ince China. ELSEVIER Travel Medicine and Infec- } \\
\text { tious Disease. } 2020 \text { May 12:101741. doi: } 10.1016 / \mathrm{j} \text {. } \\
\text { tmaid.2020.101741. }\end{array}$ & YES & ------ & $100 \%$ \\
\hline 11 & $\begin{array}{l}\text { Isaacs D, Britton PN, Preisz A (2020) Ethical reflections } \\
\text { on the COVID-19 pandemic: The epidemiology of panic. } \\
\text { WILEY Journal of Pediatrics and Child Hood. } 2020 \text { May; } \\
56 \text { (5):690-691. doi: } 10.1111 / \text { jpc.14882. }\end{array}$ & YES & ------ & $80 \%$ \\
\hline 12 & $\begin{array}{l}\text { Wunsch H (2020) Mechanical Ventilation in COVID-19: } \\
\text { Interpreting the Current Epidemiology. American Jour- } \\
\text { nal of respiratory and Critical care Medicine. } 2020 \text { May } \\
\text { 13. doi: } 10.1164 / \text { rccm.202004-1385ED. }\end{array}$ & YES & ------ & $100 \%$ \\
\hline
\end{tabular}

Table 1a: 12 Randomly selected Articles that explain the Government role in control of Pandemic of COVID-19 Novel corona virus.

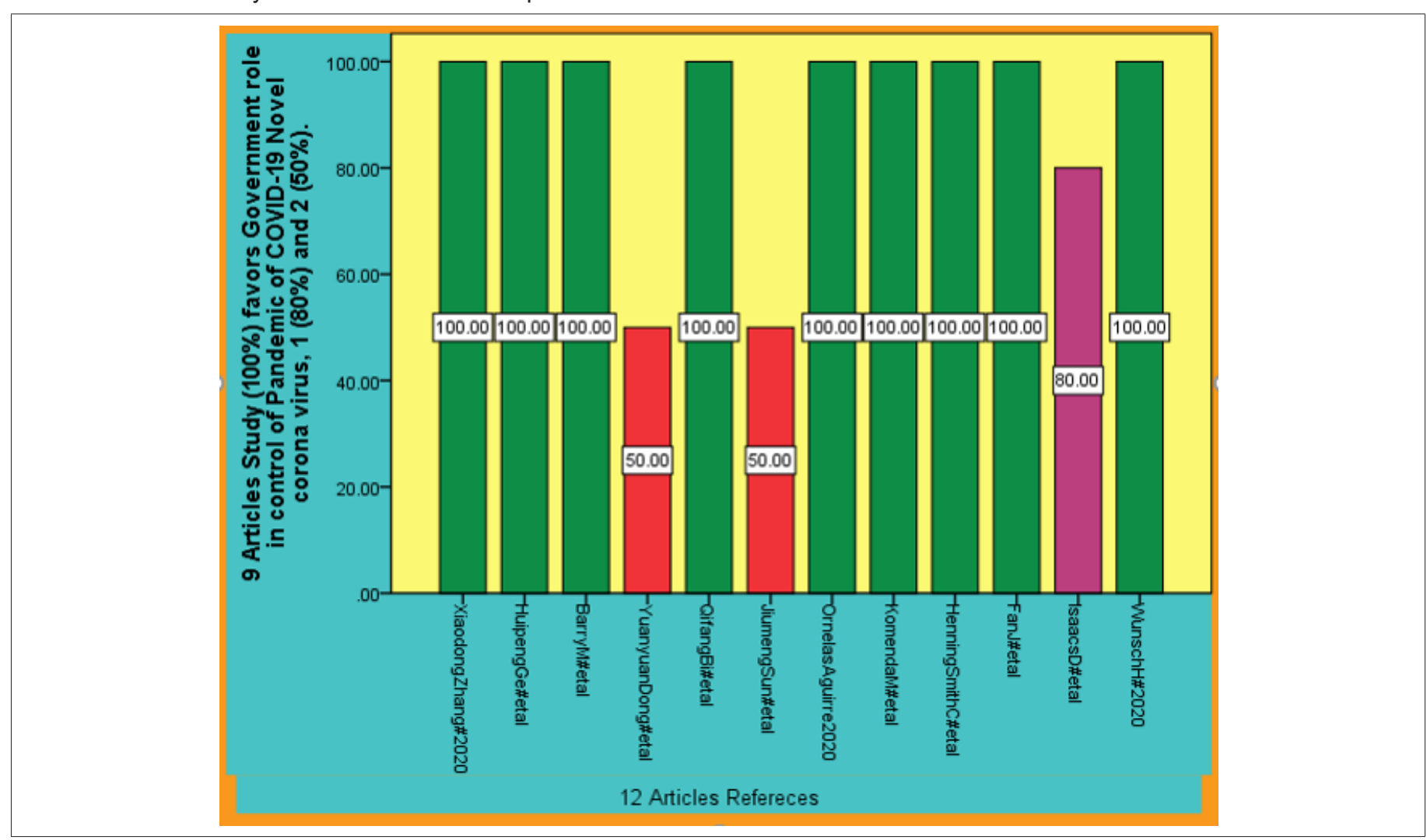

Suspension of non-essential [10] activities was declared in Mexico throughout the country in order to mitigate the spread of the COVID-19 pandemic. To analyze data on the first 1,510 labo- ratory-confirmed cases of COVID-19 in Mexico and to describe the geographical distribution of the disease and its transmission dynamics. Description of the first COVID-19 cases with real-time 
RT-PCR-positive test, as well as evaluation of epidemiological measures, cumulative incidence, rate of transmission, and mortality and lethality rates during the first month of the epidemic. Average age was 43 years, and $58 \%$ were males $44 \%$ of initial cases were imported. Lethality in the population during the first month went from 1.08 to 3.97 per 100 cases however the trend is linear and similar to that observed in Europe [10].

Table 2: 10 Randomly selected Articles discussed the Preventions for Pandemic of COVID-19 Novel corona virus.

\begin{tabular}{|c|c|c|c|}
\hline S.NO & Complete Reference of the Articles selected for study & $\begin{array}{l}\text { Articles discussed the Preventions for Pan- } \\
\text { demic of COVID-19 Novel corona virus: }\end{array}$ & $\begin{array}{l}\text { Articles Ignores discussed the } \\
\text { Preventions for Pandemic of } \\
\text { COVID-19 Novel corona virus: }\end{array}$ \\
\hline 1 & $\begin{array}{c}\text { Xiaodong Zhang (2020) Epidemiology of Covid-19. The } \\
\text { New England Journal of Medicine. 382:1869-1870. DOI: } \\
\text { 10.1056/NEJMc2005157 }\end{array}$ & YES & ------ \\
\hline 2 & $\begin{array}{l}\text { Huipeng Ge, Xiufen Wang, Xiangning Yuan, Gong Xiao et al } \\
\text { (2020) The epidemiology and clinical information about } \\
\text { COVID-19. European Journal of Clinical Microbiology } \\
\text { \& Infectious Diseases. 2020 Apr 14: 1-9. doi: 10.1007/ } \\
\text { s10096-020-03874-z. }\end{array}$ & YES & ------ \\
\hline 3 & $\begin{array}{c}\text { Barry M, Al Amri M, Memish ZA (2020) COVID-19 in the } \\
\text { Shadows of MERS-CoV in the Kingdom of Saudi Arabia. } \\
\text { Journal of Epidemiology and Global Health. } 10 \text { (1): 1-3. } \\
\text { doi: } 10.2991 / \text { jegh.k.200218.003. }\end{array}$ & YES & ------ \\
\hline 4 & $\begin{array}{l}\text { Yuanyuan Dong, Xi Mo, Yabin Hu, Xin Qi et al, (2020) } \\
\text { Epidemiology of COVID-19 Among Children in China. } \\
\text { Pediatrics Official Journal of the American Academy } \\
\text { of Pediatrics. } 145 \text { (5): e20200702; DOI: https://doi. } \\
\text { org/10.1542/peds.2020-0702. }\end{array}$ & YES & ----- \\
\hline 5 & $\begin{array}{l}\text { Qifang Bi, Yongsheng Wu, Shujiang Mei et al (2020) } \\
\text { Epidemiology and transmission of COVID-19 in } 391 \text { cases } \\
\text { and } 1286 \text { of their close contacts in Shenzhen, China: a } \\
\text { retrospective cohort study. The Lancet Infectious Diseas- } \\
\text { es. April 27, } 2020 \text { DOI:https:// doi.org/10.1016/S1473- } \\
\text { 3099(20)30287-5. }\end{array}$ & YES & ------ \\
\hline 6 & $\begin{array}{l}\text { Jiumeng Sun, Wan-Ting He, Lifang Wang et al, (2020) } \\
\text { COVID-19: Epidemiology, Evolution, and Cross-Disci- } \\
\text { plinary Perspectives. Trends in Molecular Medicine, Cell } \\
\text { Press Reviews. } 26 \text { (5): 483-495. }\end{array}$ & YES & ------ \\
\hline 7 & $\begin{array}{l}\text { Ornelas-Aguirre JM (2020) The new coronavirus that } \\
\text { came from the East: analysis of the initial epidemic in } \\
\text { Mexico. Gaceta Medica de Mexico. } 2020 \text { May 14;156 (4). }\end{array}$ & YES & ------ \\
\hline 8 & $\begin{array}{l}\text { Komenda M, Bulhart V, Karolyi M, Jarkovský J et al (2020) } \\
\text { Complex Reporting of Coronavirus Disease (COVID-19) } \\
\text { Epidemic in the Czech Republic: Use of Interactive Web- } \\
\text { Based Application in Practice. Journal of Medical Internet } \\
\text { Research. } 2020 \text { May 14. doi: } 10.2196 / 19367 .\end{array}$ & YES & ------ \\
\hline 9 & $\begin{array}{l}\text { Henning-Smith C, Tuttle M, Kozhimannil KB (2020) } \\
\text { Unequal Distribution of COVID-19 Risk among Rural Res- } \\
\text { idents by Race and Ethnicity. The Journal of Rural Health. } \\
2020 \text { May } 12 \text {. doi: } 10.1111 / \text { jrh.12463. }\end{array}$ & YES & ------ \\
\hline 10 & $\begin{array}{l}\text { Fan J, Liu X, Shao G et al (2020) The epidemiology of re- } \\
\text { verse transmission of COVID-19 in Gansu Province China. } \\
\text { ELSEVIER Travel Medicine and Infectious Disease. } 2020 \\
\text { May 12:101741. doi: } 10.1016 / \text { j.tmaid.2020.101741. }\end{array}$ & YES & ------ \\
\hline
\end{tabular}

Team of government [11] experts together with researchers focused on the design and development of a web application intended to provide a regularly updated overview of COVID-19 epidemiology in the Czech Republic to the general public. The CRISP-DM (CRoss-Industry Standard Process for Data Mining) standardized methodology for knowledge mining from database structures was chosen which provides validated information on the COVID-19 epidemic across the Czech Republic. Great emphasis was put on the understanding and a correct implementation of all six steps (business understanding, data understanding, data preparation, modelling, evaluation and deployment) needed in the process including the infrastructure of a nationwide information system. The web portal's primary objective is to publish a well-arranged visualization and clear explanation of basic information consisting of the overall numbers of performed tests confirmed cases of COVID-19, and COVID-19-related deaths together. Performed tests location 
and country of infection of COVID-19-positive persons hospitalizations of COVID-19 patients [11] and distribution of personal protective equipment.

The virus is closely related (96.3\%) to bat coronavirus [12] RaTG13 based on phylogenetic analysis. Human to human transmission has been confirmed even from asymptomatic carriers. The virus has spread to at least 200 countries and more than 1,700,000 confirmed cases and 111,600 deaths have been recorded with massive global increases in the number of cases daily. Therefore, the WHO has declared COVID-19 a pandemic. The disease is characterized by fever, dry cough, and chest pain with pneumonia in severe cases. In the beginning the world public health authorities tried to eradicate the disease in China through quarantine but are now transitioning to prevention strategies worldwide to delay its spread. To date there are no available vaccines or specific therapeutic drugs to treat the virus. There are many knowledge gaps about the newly emerged SARS-CoV-2, leading to misinformation. Therefore, in this review we provide recent information about [12] COVID-19 pandemic.

Change is already happening and rural communities [13] are leading the way. One powerful example comes from the Yurok Reservation in Northern California. In that remote rural location messaging around COVID-19 has been informed by tribal leadership to ensure that it is culturally relevant and resonant. The rapid transformation of our health and economic landscape in the wake of COVID-19 has the power to correct longstanding inequities that are particularly evident now and to ensure that rural communities especially majority non-white rural communities have sufficient access to health care services infrastructure broadband education and economic opportunity. May the legacy of our COVID-19 response be to repair the neglect faced by [13] diverse rural communities across America.

\section{Discussion}

Several independent research groups [14] have identified that SARS-CoV- 2 belongs to $\beta$-coronavirus with highly identical genome to bat coronavirus pointing to bat as the natural host. The novel coronavirus uses the same receptor angiotensin converting enzyme 2 (ACE2) as that for SARS-CoV and mainly spreads through the respiratory tract. Importantly increasingly evidence showed sustained human to human transmission along with many exported cases across the globe. The clinical symptoms of COVID-19 patients include fever, cough, fatigue and a small population of patients appeared gastrointestinal infection symptoms. The elderly and people with underlying diseases are susceptible to infection and prone to serious outcomes which may be associated with acute respiratory distress syndrome (ARDS) and cytokine storm. Currently [14] there are few specific antiviral strategies, but several potent candidates of antivirals and repurposed drugs are under urgent investigation (Figure 5).
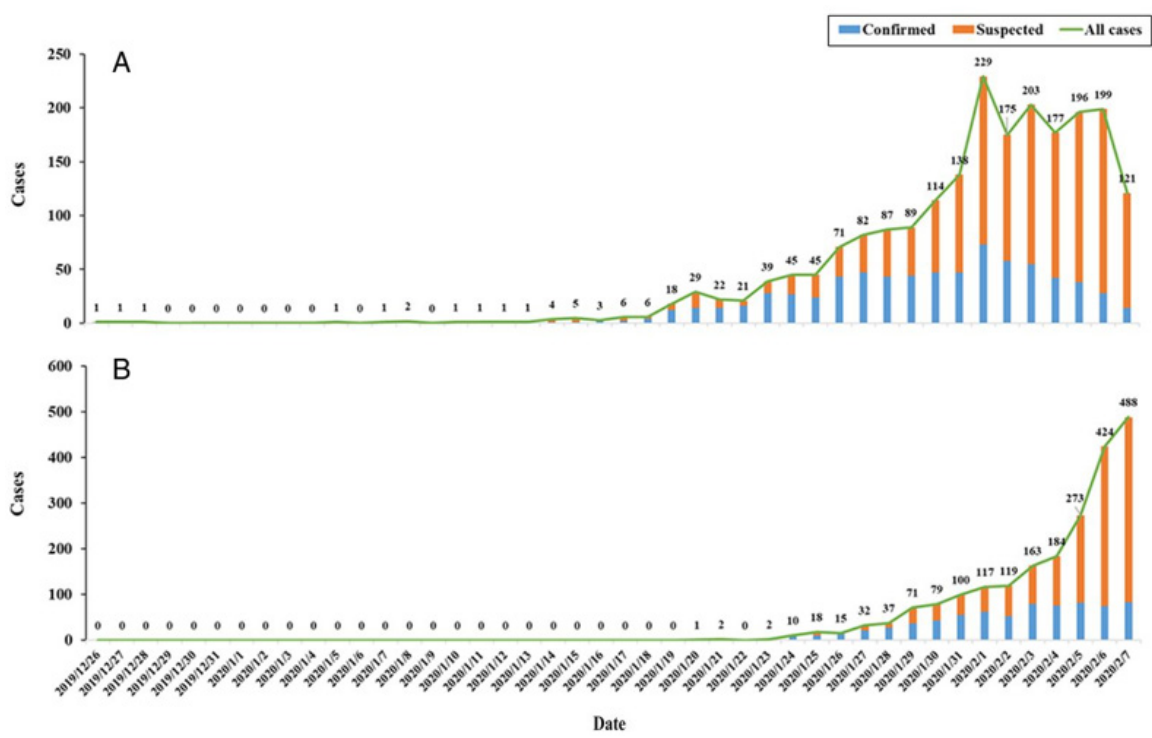

Figure 5: Onset and diagnosis dates of 2135 children's COVID-19 cases in China. A, Onset date. B, Diagnosis date. (Yuanyuan Dong, Xi Mo, Yabin $\mathrm{Hu}$, Xin Qi et al, 2020).

Professor Taisheng Li was sent to Wuhan [15] to provide frontline medical care. He depicts the clinical course of SARS-CoV-2 infection. Furthermore, he observes the significant abnormality of coagulation function and proposes that the early intravenous immunoglobulin and low molecular weight heparin anticoagulation therapy are very important. Professor Hongzhou Lu a leader in China to try various anti-viral drugs expresses concern on the quality of the ongoing clinical trials as most trials are small in scale and repetitive in nature and emphasizes the importance of the quick publication of clinical trial results. Regarding the traditional Chinese medicine Professor Lu suggests to develop a creative evaluation system because of the complicated chemical compositions. Professor Wenhong Zhang [15] is responsible for Shanghai's overall clinical management of the COVID-19 cases (Figure $6 \& 7$ ). 


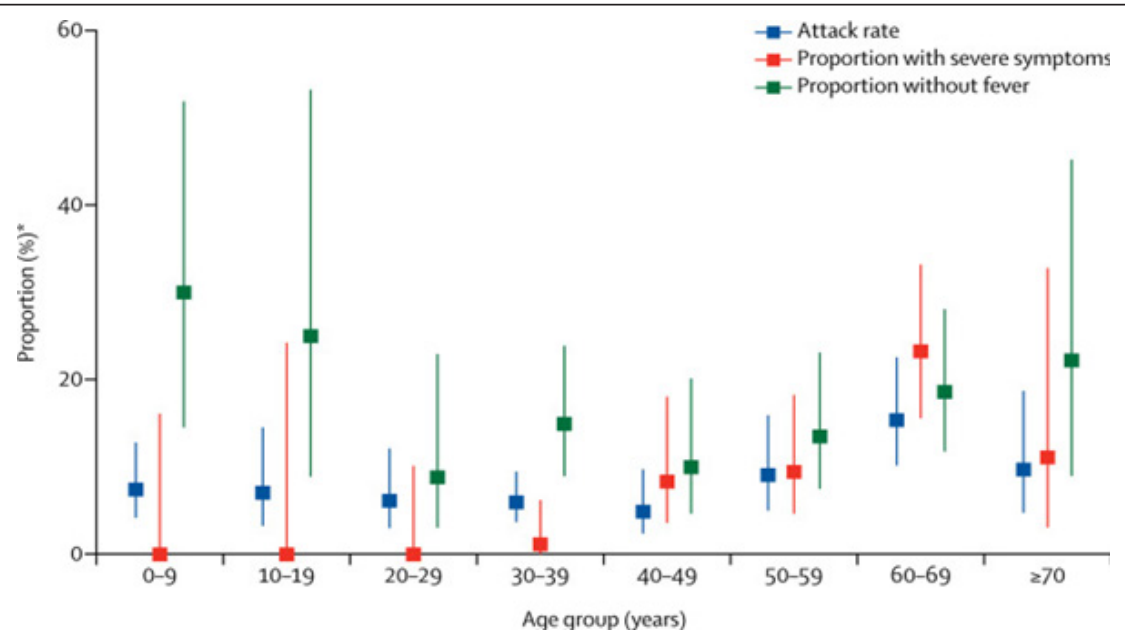

Figure 6: Demographic and clinical characteristics of cases by contact-based versus symptom-based surveillance. (Qifang $\mathrm{Bi}$, Yongsheng Wu, Shujiang Mei et al, 2020).

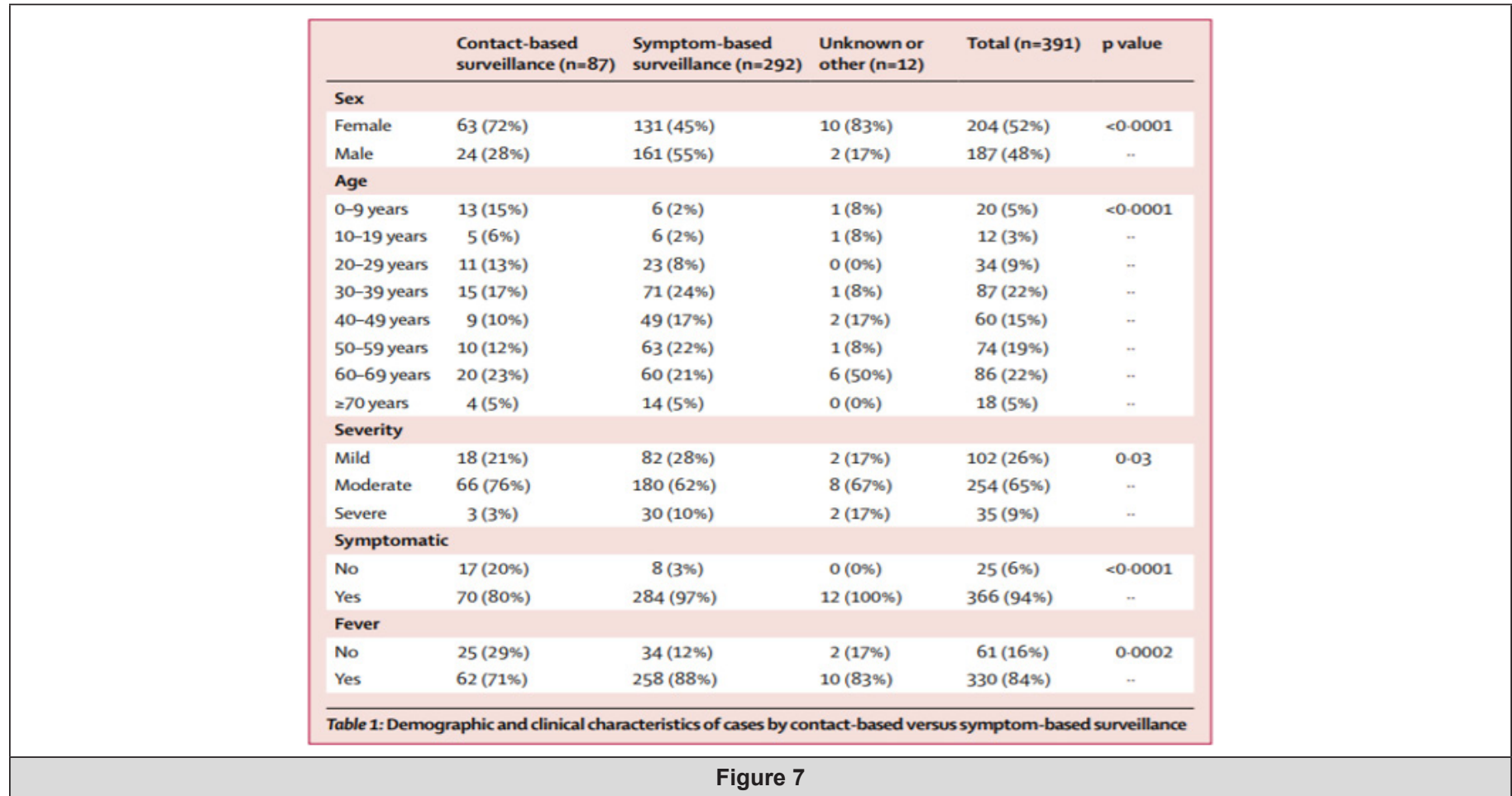

The pandemic of coronavirus disease (COVID-19) [16] a disease caused by severe acute respiratory syndrome coronavirus 2 (SARSCoV-2) is causing substantial morbidity and mortality. Older age and presence of diabetes mellitus hypertension and obesity significantly increases the risk for hospitalization and death in COVID-19 patients. In this Perspective informed by the studies on SARS-CoV-2 Middle East respiratory syndrome (MERS-CoV) and the current literature on SARS-CoV-2 we discuss potential mechanisms by which diabetes modulates the host-viral interactions and host immune responses. We hope to highlight gaps in knowledge that require further studies pertinent to COVID-19 [16] patients with diabetes.

While resource allocation will be crucial [17-19] here we would like to concentrate on questions of decision-making regarding public health measures in the face of an evolving pandemic. The Nuffield
Council on Bioethics has emphasized that Public health measures should be evidence based and proportionate. The aims of interventions should be clearly communicated to the public. Coercion and intrusion into people's lives should be kept to a minimum. People should be treated as moral equals worthy of respect. The respect due to individuals should never be forgotten when interventions such as quarantine and self-isolation are implemented, Solidarity is crucial. Public health measures designed to limit spread of a virus in this case the novel coronavirus called SARS-CoV-2 because its closest relative is the coronavirus that caused the SARS epidemic often impinge on valued civil liberties [19].

The decision to place a COVID-19 patient [20] on a ventilator is not clear cut and neither are the outcomes. We will never fully understand how or why these data from each country look so differ- 
ent. But recognizing when patterns of care and outcomes reported fall outside of one's own norms are essential to make the best use of these data for real time care. So, while we scrutinize these reports and extract what is universal and can be applied to our understanding and care of patients locally, we need to recognize and report on the enormous drivers of differences, and be vigilant in presentation of data to minimize confusion in interpretation. The variability of findings has always existed in studies of mechanical ventilation for critically ill patients. COVID-19 is not an exception [20-29] merely an amplifier of these differences.

\section{Conclusion}

Current Pandemic of COVID-19 novel corona virus has taught us a lesson that Global Health Agencies and Governments of the countries are not prepare for such Pandemic. The Governments has acted slowly or irresponsibly for the fight against COVID-19 Pandemic. Due to slow action to implement Preventive actions against COVID-19 approximately 300,000 people have lost their lives and more than four million people are Infected across the world. Better preparations are needed in the future to fight against such a cruel Pandemic disease.

\section{Reference}

1. Yuefei Jin, Haiyan Yang, Wangquan Ji, Weidong $\mathrm{Wu}$, Shuaiyin Chen, et al (2020) Virology, Epidemiology, Pathogenesis, and Control of COVID-19. Viruses 12(4): 372.

2. Usuzaki T, Chiba S, Shimoyama M (2020) How can we evaluate an interrelation of symptoms? ELSEVIER Archives of Gerontology and Geriatrics 89: 104096.

3. Huipeng Ge, Xiufen Wang, Xiangning Yuan, Gong Xiao, Chengzhi Wang, et al. (2020) The epidemiology and clinical information about COVID-19. Eur J ClincMicrobiol Infect Dis 39(6): 1011-1019.

4. Bulut C, Kato Y (2020) Epidemiology of COVID-19. Turk J Med Sci 50(SI1): 563-570.

5. Velavan TP, Meyer CG (2020) The COVID-19 Epidemic. Trop Med Int Health 25(3): 278-280.

6. Hasnain Jan, Shah Faisal, Ayyaz Khan, Shahzar Khan, Hazrat Usman, et al. (2020) COVID-19: Review of Epidemiology and Potential Treatments Against 2019 Novel Coronavirus. Discoveries 8(2): e108.

7. Qifang Bi, Yongsheng Wu, Shujiang Mei, Chenfei Ye, Xuan Zou, et al (2020) Epidemiology and transmission of COVID-19 in 391 cases and 1286 of their close contacts in Shenzhen, China: a retrospective cohort study. The Lancet Infectious Diseases.

8. Ohad Oren, Stephen L Kopecky, Tyler J Gluckman, Bernard J Gersh, Roger S Blumenthal, et al. (2020) Coronavirus Disease 2019 (COVID-19): Epidemiology, Clinical Spectrum and Implications for the Cardiovascular Clinician. American college of Cardiology.

9. Jiumeng Sun, Wan Ting He, Lifang Wang, Jiyong Zhou, Michael Veit, et al. (2020) COVID-19: Epidemiology, Evolution, and Cross-Disciplinary Perspectives. Trends in Molecular Medicine, Cell Press Reviews 26(5): 483-495.
10. Ornelas Aguirre JM (2020) The new coronavirus that came from the East: analysis of the initial epidemic in Mexico. Gac Med Mex 156(4).

11. Komenda M, Bulhart V, Karolyi M, Jarkovský J, Muzik J, et al. (2020) Complex Reporting of the (COVID-19) Epidemic in the Czech Republic: Use of Interactive Web-Based Application in Practice. J Med Internet Res 22(5): e19367.

12. Helmy YA, Fawzy M, Elaswad A, Sobieh A, Kenney SP, et al. (2020) The COVID-19 Pandemic: A Comprehensive Review of Taxonomy, Genetics, Epidemiology, Diagnosis, Treatment, and Control. J Clin Med 9(4): 1225.

13. Henning Smith C, Tuttle M, Kozhimannil KB (2020) Unequal Distribution of COVID-19 Risk among Rural Residents by Race and Ethnicity. J Rural Health.

14. Guo YR, Cao QD, Hong ZS, Tan YY, Chen SD, et al. (2020) The Origin, Transmission and Clinical Therapies on Coronavirus Disease 2019 (COVID-19) Outbreak - An Update on the Status. Mil Med Res 7(1): 11.

15. Taisheng Li, Hongzhou Lu, Wenhong Zhang (2020) Clinical Observation and Management of COVID-19 Patients. Emerg Microbes Infect 9(1): 687-690.

16. Ranganath Muniyappa, Sriram Gubb (2020) COVID-19 Pandemic, Coronaviruses, and Diabetes Mellitus. Am J Physiol Endocrinol Metab 318(5): E736-E741.

17. Google Pic (2020) Patients present to Hospital. Available at: https://ars. els-cdn.com/content/image/1-s2.0-S1386653220300998-gr3_lrg.jpg. (Accessed on: 17/05/2020)

18. Fan J, Liu X, Shao G, Qi J, Li Y, et al (2020) The epidemiology of reverse transmission of COVID-19 in Gansu Province China. Travel Med Infect Dis 101741.

19. Isaacs D, Britton PN, Preisz A (2020) Ethical reflections on the COVID-19 pandemic: The epidemiology of panic. J Pediatr Child Health 56(5): 690691.

20. Wunsch H (2020) Mechanical Ventilation in COVID-19: Interpreting the Current Epidemiology. Am J Respir Crit Care Med 202(1): 1-4.

\section{IBM (2006) IBM SPSS Software.}

22. Xiaodong Zhang (2020) Epidemiology of Covid-19. The New England Journal of Medicine 382: 1869-1870.

23. Barry M, Al Amri M, Memish ZA (2020) COVID-19 in the Shadows of MERS-CoV in the Kingdom of Saudi Arabia. J Epidemiol Glob Health 10(1): 1-3.

24. BMJ Practice (2020) Coronavirus disease 2019 (COVID-19).

25. Yuanyuan Dong, Xi Mo, Yabin Hu, Xin Qi, Fan Jiang, et al. (2020) Epidemiology of COVID-19 Among Children in China. Pediatrics 145 (5): e20200702

26. Bollyky TJ, Gostin LO, Hamburg MA (2020) The Equitable Distribution of COVID-19 Therapeutics and Vaccines. JAMA.

27. Jia JS, Lu X, Yuan Y, Xu G, Jia J, et al (2020) Population flow drives spatio-temporal distribution of COVID-19 in China. NATURE 582(7812): 389-394.

28. Minah Park, Alex R Cook, Jue Tao Lim, Yin xiaohe Sun, Borame L Dickens (2020) A Systematic Review of COVID-19 Epidemiology Based on Current Evidence. J Clin Med 9(4): 967.

29. Hussin Rothana, Siddappa Byrareddy (2020) The epidemiology and pathogenesis of coronavirus disease (COVID-19) outbreak. J Autoimmun 109: 102433 